\title{
HUBUNGAN PERSEPSI TERHADAP PENERAPAN MODEL PBM DENGAN HASIL BELAJAR SISWA PADA MATERI PERUBAHAN LINGKUNGAN
}

\author{
Subhan Abadi Nasution ${ }^{1}$, Cicik Suriani ${ }^{2}$, Geulis Endah Melinda ${ }^{3}$ \\ ${ }^{1,2}$ Program studi Pendidikan Biologi, FMIPA, Universitas Negeri Medan, Medan \\ Jl. Wiliem Iskandar Psr. V Medan Estate, Medan, Indonesia, 20221 \\ ${ }^{3}$ SMA Negeri 1 Stabat Jl. Proklamasi Stabat, Kecamatan Stabat, Kabupaten Langkat \\ E-mail: subhanabadi@gmail.com
}

\begin{abstract}
ABSTRAK
Penelitian ini bertujuan untuk mengetahui hubungan persepsi siswa terhadap penerapan model Pembelajaran Berbasis Masalah (PBM) dengan hasil belajar siswa pada materi perubahan lingkungan di kelas X di SMA Negeri 1 Stabat Tahun Pembelajaran 2017/2018.Populasi penelitian adalah seluruh siswa kelas X MIA di SMA Negeri 1 Stabat tahun pembelajaran 2017/2018. Sampel penelitian terdiri dari kelas X MIA 5 dan MIA 6 yang berjumlah 72 orang yang diambil dengan menggunakan teknik purposive sampling. Metode penelitian ini adalah deskriptif korelasional, dengan menggunakan angket dan dokumentasi hasil belajar sebagai alat pengumpul data.Berdasarkan hasil uji korelasi Product Moment diperoleh $r_{\text {hitung }}>r_{\text {tabel }}(0,57>0,235)$ artinya terdapat korelasi yang positif antara persepsi siswa terhadap penerapan model Pembelajaran Berbasis Masalah (PBM) dengan hasil belajar dan termasuk kedalam kategori sedang. Hasil uji determinasi sebesar 32,49 \% menunjukkan bahwa persepsi siswa terhadap model Pembelajaran Berbasis Masalah pada materi Perubahan Lingkungan memberikan konstribusi sebesar 32,49\% terhadap hasil belajar siswa. Pengujian hipotesis dengan menggunakan uji t diperoleh $t_{\text {hitung }}>t_{\text {tabel }}$ atau 8,62 $>1,994$. Dengan demikian $H_{0}$ ditolak dan $H_{a}$ diterima. Sehingga dapat disimpulkan bahwa ada hubungan yang signifikan antara persepsi siswa terhadap penerapan model Pembelajaran Berbasis Masalah (PBM) pada materi Perubahan Lingkungan dengan hasil belajar siswa pada materi perubahan lingkungan di kelas X di SMA Negeri 1 Stabat Tahun Pembelajaran 2017/2018.
\end{abstract}

Kata kunci : Hasil Belajar siswa, Model Pembelajaran Berbasis Masalah, Persepsi Siswa

\section{ABSTRACT}

This research aims to determine relations between students' perception about Problem Based Learning in environmental change subject matter with students learning of class X SMA Negeri 1 Stabat Academic Year 2017/2018. The population in this study were all students of class X MIA in SMA Negeri 1 Stabat. The total number of samples is 72 students. Samples were taken by purposive technique sampling. The research method used in this research is descriptive correlative, using questionnaires and documentation as data collection tools. For data analysis technique, using the formula product moment correlation coefficient values obtained correlation $r_{\text {cuount }}>r_{\text {table }}(0,57>0,235)$ it means that there is a positive and significant correlation between students' perception of Problem Based Learning model with student learning. Determination index 32,49\%, it means students' perception contributed $32,49 \%$ of the student learning. Testing the hypothesis using a statistical test $t$ obtained $t_{\text {count }}>t$ table or $8,62>1,994$. Thus $H_{0}$ is rejected and $H_{a}$ accepted. It can be concluded that there is a significant correlation between students' perception for Problem Based Learning model on change of the environment subject matter with student learning class X SMA Negeri 1 Stabat Academic Year $2017 / 2018$.

Keywords: Problem Based Learning, Student learning, Student' perception

\section{PENDAHULUAN}

Pendidikan bertujuan untuk mengembangkan potensi peserta didik agar menjadi manusia yang beriman, bertakwa kepada Tuhan yang Maha Esa, berakhlak mulia, sehat, berilmu, cakap, kreatif, mandiri, dan menjadi warga negara yang demokratis serta bertanggung jawab. Oleh karena itu, pendidikan harus mampu menyentuh potensi dan nurani peserta didik, sehingga peserta didik dapat menghadapi problema kehidupan saat di masyarakat (Trianto,2014). Untuk mencapai tujuan pendidikan nasional, tentunya dapat dicapai dengan proses belajar. Belajar pada hakikatnya adalah proses yang ditandai dengan adanya perubahan pada diri seseorang (Trianto,2014). Kenyataan dilapangan, siswa hanya menghafal konsep dan kurang mampu menggunakan konsep itu jika menemui masalah dalam kehidupannyata 
yang berhubungan dengan konsep yang dimiliki. Persoalan sekarang ialah bagaimana menemukan cara yang terbaik untuk menyampaikan berbagai konsep yang diajarkan sehingga siswa dapat menggunakan dan mengingat lebih lama konsep tersebut, bagaimana guru dapat berkomunikasi dengan siswanya, bagaimana guru dapat membuka wawasan berpikir siswa sehingga dapat mempelajari berbagai konsep dan mengaitkannya dengan kehidupan nyata serta mampu menyelesaikan masalah berdasarkan konsep yang dimiliki (Trianto, 2014).

Model Pembelajaran Berbasis Masalah (PBM) merupakan salah satu model pembelajaran yang menekankan pada penggunaan masalah sebagai titik awal akuisisi dan integrasi pengetahuan baru (Trianto,2014). Kegiatan pembelajaran pada model ini menuntut aktivitas mental siswa untuk memahami suatu konsep pembelajaran melalui situasi dan masalah yang disajikan pada awal pembelajaran dengan tujuan untuk melatih siswa menyelesaikan masalah dengan menggunakan pendekatan pemecahan masalah (Utomo et al, 2014).

Hastuti et al (2015) menjelaskan bahwa Model Problem Based Learning berbasis Scientific Approach secara signifikan meningkatkan hasil belajar biologi pada ranah kognitif siswa kelas X Di SMA Negeri 2 Bangun tapan T.A 2014/2015. Hal ini sejalan dengan penelitian yang dilakukan oleh Fauzan (2017) yang mengatakan bahwa adanya hubungan antara model pembelajaran PBL yang diterapkan dengan hasil belajar kognitif peserta didik. Peningkatan yang terjadi karena dalam penerapan model PBL peserta didik lebih terlatih dalam memecahkan berbagai permasalahan sesuai dengan kemampuan melalui penyelidikan secara autentik.

Persepsi adalah suatu proses aktivitas seseorang dalam memberikan kesan, penilaian, pendapat, merasakan dan menginterpretasikan sesuatu keadaan. Sedangkan bagian dari faktor eksternal yang dapat mempengaruhi hasil belajar adalah strategi guru mengajar termasuk diantaranya adalah penggunaan model pembelajaran. Menurut Rohmana (2016) Guru dapat menerapkan berbagai model pembelaran dengan cara tertentu yang disesuaikan dengan karakter siswa dan kondisi kelas.

Persepsi merupakan faktor yang penting dalam pencapaian hasil belajar siswa, karena persepsi dapat menjadi sebuah kekuatan dan memiliki daya dorong bagi siswa untuk belajar, sekaligus menumbuhkan rasa suka dan rasa senang untuk belajar. Persepsi yang positif perlu untuk ditumbuh kembangkan, dibina dan dipelihara agar memberi manfaat kepada peningkatan hasil belajar, untuk itu perlu mendapat perhatian dari berbagai pihak terutama guru. Bila persepsi siswa terhadap suatu pelajaran baik, maka dalam belajar siswa akan lebih bersemangat mengikuti pelajaran, akan tetapi bila persepsi siswa terhadap suatu pelajaran kurang baik maka siswa akan merasa enggan bahkan malas mengikuti pelajaran (Gani, 2015).

Berdasarkan hasil observasi yang dilakukan oleh peneliti di SMA Negeri 1 Stabat pada tanggal 05 Februari 2018 dengan cara wawancara diketahui bahwa guru belum menggunakan model pembelajaran yang bervariasi. Pembelajaran di kelas lebih sering dilakukan dengan presentasi Model pembelajaran yang kurang bervariasi membuat siswa kurang aktif dalam pembelajaran. $\mathrm{Hal}$ ini terlihat dari hasil wawancara dengan 36 siswa kelas $X$, dimana 26 siswa mengadakan bosan dengan model pembelajaran yang dilakukan, dan 10 siswa mengatakan biasa saja. Selain itu, masih banyak siswa yang belum mencapai KKM pada mata pelajaran biologi yang menandakan bahwa hasil belajar siswa belum maksimal. Dari beberapa permasalahan di atas, peneliti ingin memberikan saran kepada guru mata pelajaranuntuk melakukan pembelajaran dengan model Pembelajaran Berbasis Masalah. Saran ini bertujuan untuk melihat apakah penerapan model Pembelajaran Berbasis Masalah ini dapat mengubah persepsi siswa yang awalnya bosan, menjadi semangat dalam belajar, Peneliti juga ingin mengetahui apakah terdapat hubungan antara penerapan model Pembelajaran Berbasis Masalah dengan hasil belajarsiswa

Penelitian ini bertujuan untuk mengetahui hubungan persepsi siswa terhadap penerapan model Pembelajaran Berbasis Masalah (PBM) dengan hasil belajar siswa pada materi perubahan lingkungan di kelas $X$ di SMA Negeri 1 Stabat Tahun Pembelajaran 2017/2018. Berdasarkan uraian diatas maka perlu untuk melakukan penelitian tentang Hubungan Persepsi Siswa Terhadap Penerapan Model Pembelajaran Berbasis Masalah dengan Hasil Belajar Siswa pada Materi Perubahan Lingkungan Kelas $X$ di SMA Negeri 1 Stabat Tahun Pembelajaran 2017/2018.

\section{METODE PENELITIAN}

Penelitian ini dilaksanakan di SMA Negeri 1 Stabat yang terletak di Jl. Proklamasi, Kecamatan Stabat, Kabupaten Langkat. Penelitian dilaksanakan pada bulan April - Juni 2018. Populasi 
dalam penelitian ini adalah seluruh siswa/i kelas $\mathrm{X}$ MIA SMA Negeri 1 Stabat Tahun Pembelajaran 2017/2018 yang berjumlah enam kelas yaitu 216 orang siswa. Sampel dalam penelitian ini adalah siswa kelas X MIA 4 dan siswa kelas X MIA 6 yang berjumlah 72 orang. Teknik pengambilan sampel dalam penelitian ini menggunakan teknik purposive sampling, dimana, sampel yang diambil adalah kelas yang sudah menyelesaikan materi perubahan lingkungan dengan model PBM.

Penelitian ini merupakan penelitian ex post facto, yang dimaksud untuk menguji apa yang telah terjadi pada subyek. Desain persepsi siswa terhadap model pembelajaran berbasis masalah disebut dengan prediktor dan hasil belajar disebut dengan kriterium. Jadi penelitian ini akan melihat taraf hubungan yang terjadi antara variabel prediktor dengan kriterium.

Instrumen yang digunakan adalah angket dan dokumentasi nilai ulangan siswa. Angket digunakan untuk mengumpulkan data persepsi siswa terhadap model Pembelajaran Berbasis Masalah pada materi Perubahan Lingkungan terhadap hasil belajar dikelas X SMA Negeri 1 Stabat, terdiri dari 25 item dengan 4 alternatif jawaban. Angket tersebut diberikan dengan model tertutup yaitu bahwa pernyataan - pernyataan yang diajukan telah ditentukan jawabannya, sehingga tinggal memilih mana pernyataan yang sesuai menurut responden. Sedangkan untuk hasil belajar digunakan dokumentasi nilai ulangan siswa dengan penerapan PBM pada materi perubahan lingkungan. Untuk menentukan besar korelasi antara variabel prediktor dan kriterium maka digunakan analisis korelasi Product moment. Untuk dapat memberikan penafsiran terhadap koefisien korelasi yang didapat, maka dapat berpedoman pada Tabel 1. Sedangkan untuk mengetahui apakah terdapat hubungan yang berarti (signifikan) antara predictor dan kriterium digunakan uji t.

Tabel 1. Penafsiran koefisien korelasi

\begin{tabular}{c|c}
\hline Interval Koefisien & Tingkat Hubungan \\
\hline $0,00-0,199$ & Sangat rendah \\
\hline $0,20-0,399$ & Rendah \\
\hline $0,40-0,599$ & Sedang \\
\hline $0,60-0,799$ & Kuat \\
\hline $0,80-1,00$ & Sangat kuat \\
\hline
\end{tabular}

\section{HASIL DAN PEMBAHASAN}

Berdasarkan hasil perhitungan untuk variabel persepsi siswa terhadap model PBM dalam materi Perubahan Lingkungan diperoleh nilai $L_{\text {hitung }}\left(L_{0}\right)=0,0644$ dengan $N=72$ nilai ini dikonsultasikan dengan harga $\mathrm{L}_{(0,05 ; 72)}=0,1044$ yang hasilnya $L_{\text {hitung }}(0,0960)<L_{(0,05 ; 72)}(0,1044)$. Hal ini menunjukkan bahwa kedua kelompok data variabel persepsi siswa terhadap penerapan PBM dalam materi Perubahan Lingkungan berdistribusi normal.

Berdasarkan data yang diperoleh dari hasil jawaban siswa terhadap angket persepsi siswa pada model PBM dalam materi Perubahan Lingkungan diperoleh skor tertinggi yaitu 91 dan skor terendah yaitu 67 dengan rata - rata $(\bar{X})=$ 81.94 dan standar deviasi $(S D)=4,59$. Penafsiran tingkat kecenderungan skor persepsi siswa pada model PBM dapat dilihat pada tabel 1. Sedangkan untuk hasil belajar siswa dapat dilihat pada tabel 2 .

Tabel 1. Persepsi Siswa terhadap Penerapan Model PBM

\begin{tabular}{cccccc}
\hline \multirow{2}{*}{ NO } & \multicolumn{2}{c}{ Persepsi Siswa } & Frekuensi & $\begin{array}{c}\text { Frekuensi } \\
\text { Absolut }\end{array}$ & Kategori \\
\cline { 2 - 3 } & Kategori & Skor & Relif & \\
\hline 1 & Sangat Baik & 85 keatas & 24 & $33,33 \%$ & Tinggi \\
2 & Baik & $79-84$ & 30 & $41,67 \%$ & Cukup \\
3 & Tidak Baik & $73-78$ & 16 & $22,22 \%$ & Kurang \\
4 & Sangat Tidak Baik & $<72$ & 2 & $2,78 \%$ & Rendah \\
\hline
\end{tabular}

Tabel 2. Hasil Belajar Siswa Terhadap Penerapan Model PBM

\begin{tabular}{ccccc}
\hline No & Skor & Frekuensi Absolut & Frekuensi Relatif & Kategori \\
\hline 1 & 84 keatas & 19 & $26,39 \%$ & Tinggi \\
2 & $80-83$ & 15 & $20,83 \%$ & Cukup \\
3 & $76-79$ & 21 & $33,33 \%$ & Kurang \\
4 & $<75$ & 17 & $23,61 \%$ & Rendah \\
\hline
\end{tabular}

Dari tabel 1 dapat diketahui bahwa terdapat 24 orang siswa (33,33\%) yang memiliki persepsi sangat baik terhadap penerapan PBM, 30 orang siswa memiliki persepsi baik terhadap penerapan PBM (41,67\%), 16 orang siswa memiliki persepsi tidak baik $(22,22 \%)$ dan 2 orang siswa (3,33\%) dengan memiliki persepsi sangat tidak baik. Dengan demikian berdasarkan hasil 
perhitungan, persentase tertinggi persepsi siswa terhadap model PBM adalah pada kategori baik dengan jumlah responden sebanyak 30 orang siswa (41,67\%). Sehingga skor persepsi siswa terhadap model PBM pada materi Perubahan Lingkungan di kelas X SMA Negeri 1 Stabat Tahun Pembelajaran 2016/2017 cenderung cukup.

Dari tabel 2 dapat diketahui bahwa terdapat 19 orang siswa $(26,39 \%)$ yang memiliki hasilbelajar dengan kategori tinggi, 15 orang siswa $(20,83 \%)$ dengan hasilbelajar dalam katerogi cukup, 21 orang siswa $(33,33 \%)$ dengan kategori kurang dan 17orang siswa $(23,61 \%)$ dengan kategori hasil belajar rendah. Dengan demikian dapat disimpulkan bahwa yang memiliki persentase tertinggi adalah pada kategori kurang dengan jumlah responden sebanyak 21 orang siswa.

Hipotesis alternatif $\mathrm{H}_{\mathrm{a}}$ diterima apabila $1 \leq r \leq 1 ; r \neq 0$ pada taraf signifikan $\alpha=0,05$. Diperoleh harga $r_{x y}=0,57$ atau $-1 \leq 0,57 \leq 1$. Dengan demikian diperoleh korelasi positif antara persepsi siswa terhadap penerapan model PBM dan hasil belajar siswa pada materi perubahan lingkungan. Dimana, semakin positif persepsi siswa terhadap penerapan model PBM akan meningkatkan hasil belajar siswa. Kemudian harga koefisien korelasi $r_{x y}$ dibandingkan dengan harga $r_{(0,05 ; 70)}=0,235$ Maka diperoleh nilai $r_{\text {hitung }}>r_{\text {tabel }}$. Itu artinya hipotesis alternatif yang menyatakan adanya hubungan persepsi siswa terhadap penerapan model PBM dan hasil belajar siswa kelas $X$ di SMA Negeri 1 Stabat Tahun Pembelajaran 2017/2018 diterima. Dengan koefisien 0,57 yang termasuk dalam kategori sedang.

Dari hasil pengujian hipotesis hipotesis dengan analisis regresi sederhana pada penelitian ini menunjukkan $r_{x y}=0,57$ penelitian ini sesuai dengan hipotesis yang diajukan, bahwa terdapat hubungan positif yang signifikan antara variabel persepsi terhadap penerapan model PBM dengan hasil belajar siswa. Dimana, semakin positif perseps isiswa terhadap PBM, maka akan meningkatkan hasil belajar siswa. Dari uji determinasi diperoleh $\mathrm{I}=32 \%$ Hal ini menunjukkan, persepsi terhadap PBM memberikan kontribusi sebesar 32\% terhadap hasil belajar siswa.

Berdasarkan hasil deskripsi data penelitian, terdapat 24 orang siswa (33,33\%) yang memiliki persepsi sangat baik terhadap penerapan PBM, 30 orang siswa memiliki persepsi baik terhadap penerapan PBM (41,67\%), 16 orang siswa memiliki persepsi tidak baik $(22,22 \%)$ dan 2 orang siswa (3,33\%) dengan memiliki persepsi sangat tidak baik. Persentase persepsi siswa terhadap model PBM termasuk kedalam kategori baik dengan kecenderungan cukup (41,67\%). Sedangkan untuk hasil belajar siswa diperoleh data 19 orang siswa (26,39\%) yang memiliki hasil belajar dengan kategori tinggi, 15 orang siswa $(20,83 \%)$ dengan hasil belajar dalam katerogi cukup, 21 orang siswa (33,33\%) dengan kategori kurang dan 17orang siswa (23,61\%) dengan kategori hasil belajar rendah. Dengan demikian dapat diketahui bahwa yang memiliki persentase tertinggi adalah pada kategori kurang dengan jumlah responden sebanyak 21 orang siswa.

Dari hasil pengujian hipotesis dengan analisis regresi sederhana pada penelitian ini menunjukkan $r_{x y}=0,57$. Penelitian ini sesuai dengan hipotesis yang diajukan, bahwa terdapat hubungan positif yang signifikan antara variabel persepsi terhadap penerapan model PBM dengan hasil belajar siswa. Dimana, semakin positif persepsi siswa terhadap PBM, maka akan meningkatkan hasil belajar siswa. Dari uji determinasi diperoleh $\mathrm{I}=32 \%$ Hal ini menunjukkan, persepsi terhadap PBM memberikan kontribusi sebesar 32\% terhadap hasil belajar siswa.

Berdasarkan hasil penelitian terlihat bahwa persepsi merupakan faktor penting dalam proses pembelajaran, artinya jika persepsi siswa baik terhadap metode atau model yang digunakan, maka akan mempengaruhi hasil belajar siswa. Sesuai dengan yang dikemukakan oleh Gani (2015) bahwa persepsi merupakan faktor yang penting dalam pencapaian hasil belajar siswa, karena persepsi dapat menjadi sebuah kekuatan dan memiliki daya dorong bagi siswa untuk belajar, sekaligus menumbuhkan rasa suka dan rasa senang untuk belajar.

Persepsi yang positif perlu untuk ditumbuhkembangkan, dibina dan dipelihara agar memberi manfaat kepada peningkatan hasil belajar, untuk itu perlu mendapat perhatian dari berbagai pihak terutama guru. Bila persepsi siswa terhadap suatu pelajaran baik, maka dalam belajar siswa akan lebih bersemangat mengikuti pelajaran, akan tetapi bila persepsi siswa terhadap suatu pelajaran kurang baik maka siswa akan merasa enggan bahkan malas mengikuti pelajaran.

Selain itu, persepsi juga penting karena dapat meningkatkan motivasi belajar siswa, sesuai dengan hasil penelitian yang dilakukan oleh Pramitasari et al (2011) bahwa terdapat hubungan positif yang signifikan persepsi terhadap pembelajaran kontekstual dengan motivasi 
belajarsiswa, dengan sumbangan efektif sebesar $64,7 \%$.

Sementara itu, jika dilihat dari hasil jawaban siswa pada tiap indikator angket, untuk angket persepsi siswa padapenerapan model PBM, dengan rata - rata skor tertinggi adalah 3,63 terdapat pada indikator menghargai pendapat teman dengan deskriptor menghargai pendapat teman dan meningkatkan kerjasama kelompok. Dari hasil ini terlihat bahwa PBM dapat membuat siswa lebih menghargai pendapat teman dan meningkatkan kerjasama kelompok dikelas dalam proses pembelajaran yang ditunjukkan dengan proses diskusi dan menyimpulkan hasil diskusi baik dalam kelompok maupun dengan teman di kelas.

Hal ini didukung oleh hasil penelitian yang dilakukan Hadijah (2014) bahwa penerapan model PBM dapat meningkatkan motivasi belajar siswa (76,0\%), aktivitas siswa dan hasil belajar biologi siswa.

\section{KESIMPULAN}

Persepsi siswa terhadap penerapan model PBM pada materi perubahan lingkungan di kelas $X$ MIA SMA Negeri 1 Stabat Tahun Pembelajaran 2017/2018 termasuk kedalam kategori cukup dengan persentase sebesar $41,67 \%$

Hasil belajar siswa kelas X MIA SMA Negeri 1 Stabat pada materi perubahan lingkungan Tahun Pembelajaran 2017/2018 termasuk kedalam kategori cukup dengan persentase sebesar $33,33 \%$.

Terdapat hubungan positif yang signifikan antara persepsi siswa terhadap penerapan model PBM pada materi perubahan lingkungan dengan hasil belajar di kelas X MIA SMA Negeri 1 Stabat Tahun Pembelajaran 2017/2018. Semakin positif persepsi siswa terhadap penerapan model PBM akan meningkatkan hasil belajar siswa. Dimana persepsi siswa memberikan kontribusi sebesar $32 \%$ pada hasil belajar siswa.

\section{DAFTAR PUSTAKA}

Abdurrazak, Rizal, Asep Kurnia Jayadinata, Isrok 'atun, 2016, Pengaruh Model Problem Based Learning Terhadap Kemampuan Berpikir Kreatif Siswa, Jurnal Pena IImiah 1 (1).

Al- Tabany, Trianto,I,B, (2014), Mendesain Model Pembelajaran Inovatif, Progresif, Dan Kontekstual, Jakarta. Prenada media Group.
Fauzan, M., Gani, A., dan Syukri, M., 2017, Penerapan Model Problem Based Learning Pada Pembelajaran Materi Sistem Tata Surya Untuk Meningkatkan Hasil Belajar Siswa, Jurnal Pendidikan Sains Indonesia, 5 (1).

Gani, Abdul, (2015), Pengaruh Model Pembelajaran Dan Persepsi Tentang Matematika Terhadap Minat Dan Hasil Belajar Matematika Siswa SMP Negeri Di Kecamatan Salomekko Kabupaten Bone, Jurnal Daya matematis, 3 (3).

Hadijah, Sitti, (2014). Peningkatan Motivasi, Aktivitas, Dan Hasil Belajar Siswa Pada Materi Ekosistem Melalui Penerapan Model Pembelajaran Problem Based Learning Kelas VII f Smp Negeri 3 Palopo, 1(1)

Hastuti, Dwi Reni, Dian Noviar. Pengaruh Model Problem Based Learning (PBL) Berbasis Scientific Approach terhadap Hasil Belajar Biologi Siswa Kelas X di SMAN 2 Banguntapan T.A. 2014/2015. Bioedukasi 8 (2).

Pramitasari, Amelia, Yeniar Indriana, Jati Ariati. (2011). Hubungan Antara Persepsi Terhadap Metode Pembelajaran Kontekstual Dengan Motivasi Belajar Biologi Siswa Kelas X Ipa SMAN 1 Pangkalan Kerinci, Riau. Jurnal Psikologi Undip 9 (1).

Rohmana, Qorry Aulia., Nur, Widodo., Listijo, Kapti., 2016, Penerapan Model Pembelajaran TSTS ( Two Stay Two Stray) Dipadu Picture And Picture Untuk Meningkatkan Keaktifan Dan Hasil Belajar Materi Jaringan Hewan Pada Siswa Kelas XI SMA. Jurnal Pendidikan 1 (10).

Utomo, Tomi, Dwi Wahyuni, Slamet Hariyadi, 2014, Pengaruh Model Pembelajaran Berbasis Masalah (Problem Based Learning) Terhadap Pemahaman Konsep dan Kemampuan Berpikir Kreatif Siswa (Siswa Kelas VIII Semester Gasal SMPN 1 Sumbermalang Kabupaten Situbondo Tahun Ajaran 2012/2013). JURNAL EDUKASI UNEJ 2014, I (1): 5-9. 